\title{
EFFECTS OF DIFFERENT AMENDMENTS (ORGANIC MATTER AND HYDROGEL) ON THE ACTUAL EVAPOTRANSPIRATION AND CROP COEFFICIENT OF TURF GRASS UNDER FIELD CONDITIONS ${ }^{\dagger}$
}

\author{
GLADYS L. BANDENAY ${ }^{1}$, ARIANNA RENAU-PRUÑONOSA ${ }^{2 *}$, IGNACIO MORELL ${ }^{3}$
} AND MARÍA V. ESTELLER ${ }^{4}$

\author{
${ }^{1}$ Universidad de Ingeniería y Tecnología. UTEC. Barranco, Lima, Perú \\ ${ }^{2}$ Department of Botany and Geology, University of Valencia, Burjassot, Valencia, Spain \\ ${ }^{3}$ Research Institute of Pesticides and Water (IUPA), Jaume I University, Castelló, Spain \\ ${ }^{4}$ Instituto Interamericano de Tecnología y Ciencias del Agua (IITCA), Universidad Autónoma del Estado \\ de México, San Cayetano Morelos, Toluca, México
}

\begin{abstract}
Irrigation schedule in arid areas has to be efficient in order to reduce losses due to evaporation and deep infiltration. Irrigation optimization poses the need to establish with precision the value of actual evapotranspiration $\left(\mathrm{ET}_{\mathrm{a}}\right)$, and crop coefficient $\left(\mathrm{K}_{\mathrm{c}}\right)$. The water soil availability can be increased using hydrogel and organic matter amendments, theirs effects could vary $\mathrm{ET}_{\mathrm{a}}$ and $\mathrm{K}_{\mathrm{c}}$. The aim of this study was to determine the $\mathrm{ET}_{\mathrm{a}}$, and $\mathrm{K}_{\mathrm{c}}$ of an experimental site with lysimeters on the Spanish Mediterranean coast cropped with a turf grass variety, Agrostis stolonifera -L-93, under field conditions, and amended with hydrogel and organic matter.

Reference evapotranspiration $\left(\mathrm{ET}_{0}\right)$ was determined from meteorological data (FAOPenman-Monteith equation). $\mathrm{ET}_{\mathrm{a}}$ was calculated from the water balance, and $\mathrm{K}_{\mathrm{c}}$ was obtained by dividing $\mathrm{ET}_{\mathrm{a}}$ by $\mathrm{ET}_{0} . \mathrm{K}_{\mathrm{c}}$ was calculated and compared on a yearly, monthly and daily basis. In summer, the differences between amendments become manifest:Unamended lysimeter $(100 \%$ sand) had $K_{c}$ values (0.92-1.16), similar to organic matter amended lysimeter (0.99-1.17). Maximum and minimum $\mathrm{K}_{\mathrm{c}}$ values for the hydrogel amended lysimeters (1.04-1.52) were higher

\footnotetext{
${ }^{\dagger}$ Effets de différents amandments (matière organique et hydrogel) sur l'évaporation réelle et le coefficient de culture du gazon de gazon dans les conditions du terrain

* Correspondence to: Prof. Arianna Renau-Pruñonosa. Universitat Jaume I - IUPA. Sos Baynat S/N Campus Borriol Castello de la Plana 12071. Spain. Tel.: 0034964307381. E-mail: arenau @uji.es
} 
than those from the other because of the ability of this compound to retain water, which facilitated evapotranspiration. Finally, hydrogel helped to maintain the turf grass quality.

KEY WORDS: Lysimeters, crop coefficient $\left(\mathrm{K}_{\mathrm{c}}\right)$, evapotranspiration $\left(\mathrm{ET}_{\mathrm{a}}\right)$, organic matter, hydrogel, Mediterranean climate

\section{RÉSUMÉ}

La planification de l'irrigation dans des zones arides doit être efficace afin de réduire les pertes par évaporation et infiltration profonde. L'optimisation de l'irrigation nécessite définir avec précision la valeur réelle d'évapotranspiration $\left(\mathrm{ET}_{\mathrm{a}}\right)$ ainsi que celle du coefficient d'agriculture $\left(\mathrm{K}_{\mathrm{c}}\right)$. L'objectif de cette étude était de déterminer la $\mathrm{ET}_{\mathrm{a}}$ et le $\mathrm{K}_{\mathrm{c}}$ d'une pelouse expérimentale cultivée sur la côte méditerranéenne avec une variété de gazon, Agrostis stolonifera-L-93, en conditions naturelles et modifié avec de l'hydrogel et de la matière organique.

L'évapotranspiration de référence $\left(\mathrm{ET}_{0}\right)$ a été déterminée à partir de données météorologiques (équation FAO-Penman-Monteith). $\mathrm{L}^{\prime} \mathrm{ET}_{\mathrm{a}}$ a été calculée à partir de l'équilibre d'eau, et le $\mathrm{K}_{\mathrm{c}}$ a été obtenu en divisant la $\mathrm{ET}_{\mathrm{a}}$ par la $\mathrm{ET}_{0}$. Le $\mathrm{K}_{\mathrm{c}}$ a été calculé et comparé quotidiennement, mensuellement et annuellement. En été de façon significative et les différences entre les modifications deviennent alors évidentes: Un lysimètre non modifiée (100\% sable) avait des valeurs de $\mathrm{K}_{\mathrm{c}}(0.92-1.16)$, similaires à celle d'un lysimètre modifiée par matière organique (0.99-1.17). Les valeurs maximum et minimum du $\mathrm{K}_{\mathrm{c}}$ sur les lysimètres modifiées par hydrogel (1.04-1.52) étaient plus grandes que celles des autres en raison de la capacité du composé à retenir l'eau en surface (ce qui facilita l'évapotranspiration). Finalement, l'hydrogel facilite ainsi la maintenance de la qualité du gazon.

MOTS CLÉS: Lysimètre, coefficient d'agriculture $\left(\mathrm{K}_{\mathrm{c}}\right)$, évapotranspiration $\left(\mathrm{ET}_{\mathrm{a}}\right)$, matière organique, climat méditerranéen

\section{INTRODUCTION}

Evapotranspiration is the combination of two separate processes whereby water is lost from the soil: evaporation and transpiration. Evaporation consists in the vaporization of water due to solar radiation, temperature, wind and other meteorological factors, and transpiration consists of the vaporization of liquid water contained in plant tissues and its removal to the atmosphere. Since 
both processes occur simultaneously and there is no easy way of distinguishing between them, they are compiled in a single term: evapotranspiration (Allen, 1998). Evapotranspiration can be measured in experimental lysimeters (actual evapotranspiration, ET $_{\mathrm{a}}$ ) or estimated from meteorological data (reference evapotranspiration, $\mathrm{ET}_{0}$ ).

The $\mathrm{ET}_{\mathrm{a}}$ can be determined from the water balance and depends on the type of crop, the characteristics of the substrate, soil moisture, agronomic activities, and climatic conditions (intensity and frequency of rainfall, temperature, solar radiation, wind speed, and relative humidity) (Shearman and Beard 1973; Xinmin et al., 2007; Wherley et al., 2015; Amgain et al., 2018). In addition, as pointed out by Biran et al. (1981), and Kneebone and Pepper (1984), we must account for the fact that the $\mathrm{ET}_{\mathrm{a}}$ increases when water is available. Aronson et al. (1987) and Blankenship (2011) noted that evapotranspiration was governed mainly by meteorological factors when there was enough moisture in the soil, but that it declined after a critical level of moisture was reached.

On the other hand, $\mathrm{ET}_{0}$ is estimated from meteorological data (precipitation, solar radiation, maximum and minimum temperature, wind speed, and relative humidity) using the FAOPenman-Monteith equation (Smith et al., 1992; Allen et al., 1998).

Under standard conditions (well-watered conditions) the $\mathrm{ET}_{\mathrm{a}}$ of a crop can be related to the $\mathrm{ET}_{0}$ through the crop coefficient, $\mathrm{K}_{\mathrm{c}}$ (ASCE 1990; Zhang et al., 2010; Marin et al. 2016). The $\mathrm{K}_{\mathrm{c}}$ refers to the characteristics that distinguish the studied crop from a reference crop under standard (well-watered) conditions. It varies with the nature of the crop, its height and stage of development, the supporting substrate, and the climatic characteristics of the area. The $\mathrm{K}_{\mathrm{c}}$ shows daily variation and, to minimize complexity, is expressed as the average over a period, either monthly, yearly, by stage of crop development, or season (Allen et al., 1998).

The installation and maintenance of golf courses constitute a demanding agricultural activity involving the intensive cultivation of large areas of grass that require significant quantities of water for irrigation (Rodriguez-Diaz et al., 2007). The use of different grass according to weather conditions seeks to increase the efficiency of irrigation, and $\mathrm{ET}_{\mathrm{a}}$ varies according to the variety of grass. $\mathrm{ET}_{\mathrm{a}}$ from cool season and warm season grasses ranges from 3 to $8 \mathrm{~mm} / \mathrm{day}$ and from 2 to 6 mm/day, respectively (Augustin, 2000; Huang, 2006; Xinmin et al., 2007, Wherley et al., 2015, Colmer and Barton, 2017). When the water availability drops, the grass responds to the shortage by activating biological mechanisms that result in lower water consumption. As reported by McCann and Huang (2008), the Agrostis stolonifera-L-93 variety generally suffers a sharp decline in the rate of $\mathrm{ET}_{\mathrm{a}}$ in low water stress conditions, and, as indicated by $\mathrm{Xu}$ and Huang (2000), Liu and Huang (2001) and Da Costa and Huang (2006a, b), also suffers from biological changes that are triggered to reduce water consumption. Numerous studies have reported different 
values of $\mathrm{K}_{\mathrm{c}}$ for the same grass variety, reflecting the influence of the growing area. For example, the $\mathrm{K}_{\mathrm{c}}$ value of the Bermuda grass (Cynodon dactylon) variety ranges is between 0.17 and 0.99 in south eastern USA (Wherley et al., 2015). Kentucky bluegrass has $\mathrm{K}_{\mathrm{c}}$ values is between 0.80 and 1.40 in Beijing, and $\mathrm{K}_{\mathrm{c}}$ of Tall fescue is 0.5 and 0.8 in Colorado, and ranges from 0.84 to 1.49 in Beijing (Erwin and Koski, 1998; Fu et al., 2004; Xinmin et al., 2007).

For this study, carried out under Mediterranean climatic conditions, an experimental golf green comprised by four sand based lysimeters was built. The actual water requirement $\left(\mathrm{ET}_{\mathrm{a}}\right)$ of a maintained Agrostis stolonifera- $L-93$ creeping turf grass was determined under both total water availability and water stress conditions. Since the sand based lysimeters were amended with organic matter (OM) and hydrogel, an evaluation of the effect of these amendments on the $\mathrm{ET}_{\mathrm{a}}$ and $\mathrm{K}_{\mathrm{c}}$ could be made.

The addition of OM and hydrogel amendments is a common practice since it increases efficiency in water and agrochemicals use (Aamlid et al., 2009; Ullah et al., 2015; Martin del Campo et al., 2019). Hydrogels are hydrophilic polymers that absorb water, improve soil porosity, aeration, infiltration, nutrient transport and release, and water absorption that promote plant growing (Akhter et al., 2004; Abedi-Koupai et al., 2008; Ullah et al., 2015).

\section{MATERIALS AND METHODS}

\section{Description of the experimental green}

Four lysimeters were built, each with a surface of approximately $40 \mathrm{~m}^{2}$ and a volume of 11 $\mathrm{m}^{3}$. The substrate is composed of a $26-40 \mathrm{~cm}$ sandy base (substrate categorized by the United States Golf Association (USGA) as siliceous sand), overlaying a 10-cm gravel layer containing drainage pipes $(7.5 \mathrm{~cm}$ diameter) that collect water and drain them toward the exit. At the exit, recipients collect drainage water for control purposes. Water drainage samples were collected daily.

Each lysimeter is coated on the bottom and sides with a geomembrane that independently collects and channels all infiltrated water toward the drainage exit.

The addition of the OM and hydrogel in the lysimeters was carried out on the already deposited sand, and it was mixed with the first $10 \mathrm{~cm}$ of the sandy substrate. The lysimeters are amended as follows: P-1 is amended with both: $20 \%$ OM (peat) and $145 \mathrm{~g} / \mathrm{m}^{2}$ hydrogel, P-2 is amended with $20 \%$ OM (constructed according to USGA requirements), and P-3 is amended with $145 \mathrm{~g} / \mathrm{m}^{2}$ hydrogel (TerraCottem ${ }^{\circledR}$ ). P-4 is sand only.

Each lysimeter has an independent irrigation system. Each irrigation system comprises 
eight diffusers (Model 6406-ADV Nelson Turf®) equipped with $15 \mathrm{~cm}$ body type nozzles (7370 Multiarc). Each system is controlled by an electric pump and a counter. Although irrigation is programmed, the flow is not always the same and depends on different factors, such as water pressure in the main pipes and water availability. Flow rates in lysimeters vary between 23.4 and $39.0 \mathrm{~mm} / \mathrm{h}$. The determination of the water that falls within each lysimeter was made assuming that the irrigation is uniform. Irrigation during the investigation was scheduled according to rainfall and the objectives pursued: i) Total water availability: the condition of total water availability was maintained through most of 2010; ii) Tracer tests: tests that involved high water inputs were carried from December 2010 to May 2011, and iii) Water stress: a slight water stress was imposed in the period from June to December 2011 to determine if irrigation water could be saved in comparison to 2010 .

The lysimeters are equipped with three moisture sensors installed vertically (DECAGON). Two sensors are the 10HS type that measures the volumetric moisture at depths of 12 and $24 \mathrm{~cm}$, respectively, while the other one is the 5 TE type, installed at a depth of about $18 \mathrm{~cm}$, which also measures the electrical conductivity and temperature. They were all calibrated for the substrate in which they were installed and were set up to record data every 2 minutes.

A meteorological station (Weather Rain Bird Smart), installed next to the green, provided hourly precipitation, solar radiation, maximum and minimum temperature, wind speed, and relative humidity data. We used the data from this station to calculate the $\mathrm{ET}_{0}$ from the FAOPenman-Monteith equation (Smith et al., 1992; Allen et al., 1998).

Apart from the irrigation rates, which were modified to meet the requirements of each lysimeter, the experimental site was treated in the same way (watering, mowing, fertilizing, phytosanitary treatment, pricked, and verticutting) as the other greens in the golf course.

Data were collected from these lysimeters for 3 years (2009-2011). 


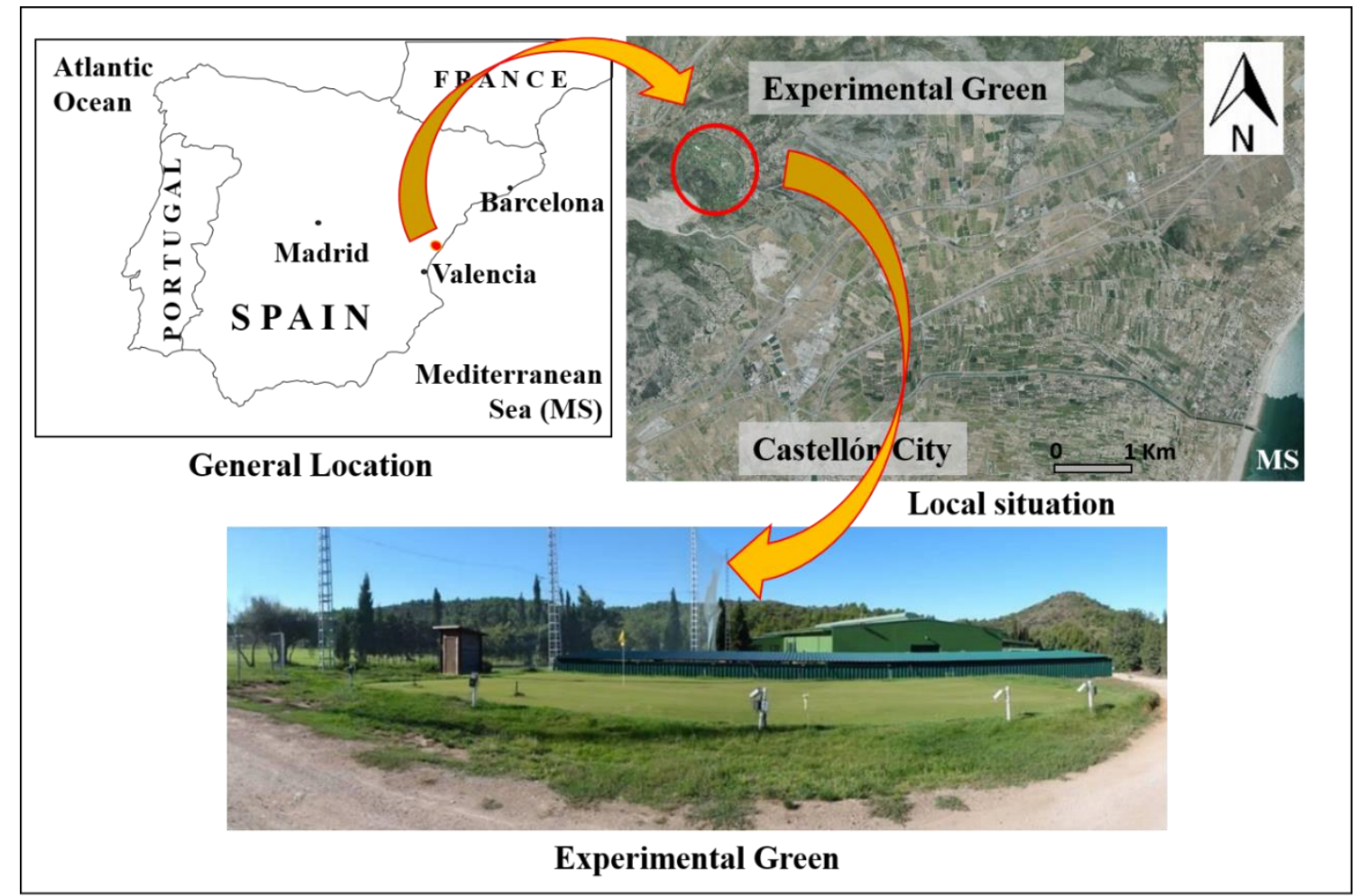

Figure 1. Location of the field study site

\section{Climatic characteristics of the area}

The experimental green is located a few kilometres from the Mediterranean coast in Spain (Figure 1). The area is characterised by a mild and humid Mediterranean climate. According to the meteorological data obtained from the meteorological station of the experimental green, the average temperatures in the warmer months during the study period were about $23{ }^{\circ} \mathrm{C}$, with peak point temperatures close to $30{ }^{\circ} \mathrm{C}$. On the other hand, the average temperatures for the winter months were between 8 and $10{ }^{\circ} \mathrm{C}$, with minimum temperatures of $2-3{ }^{\circ} \mathrm{C}$. During the period from 2009 to 2011, the months with the lowest rainfall were July 2010 and August 2011, with no rainfall. In contrast, the rainy month was September 2009 with a rainfall of $360 \mathrm{~mm}$, followed by November 2011 with $182 \mathrm{~mm}$ (Figure 2). 


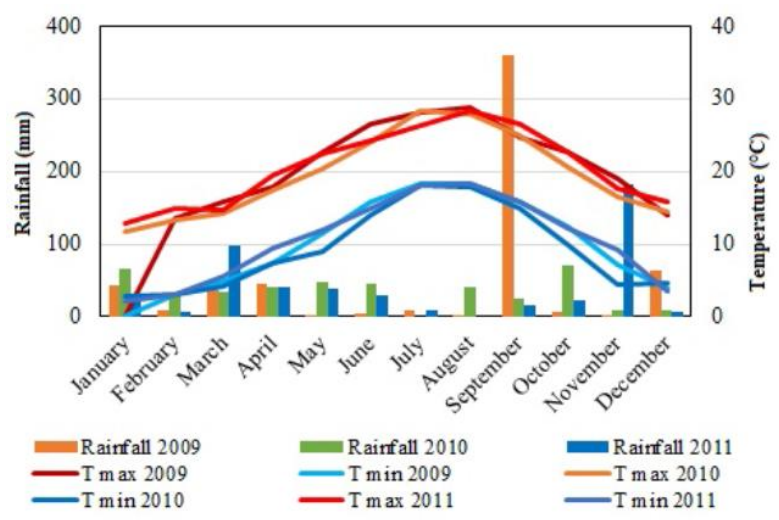

Figure 2. Temperatures and rainfall (2009-2010). Data from the meteorological station of experimental site

Reference evapotranspiration ( $\left.E T_{0}\right)$

$\mathrm{ET}_{0}$ is usually estimated from meteorological data, which were obtained from the installed meteorological station. The FAO-Penman-Monteith equation is the most widely-accepted method for calculating $\mathrm{ET}_{0}$ (Smith et al., 1992; Allen et al., 1998):

$E T_{o}=\frac{0,408(R n \quad G)+\frac{900}{T+273} U_{2}\left(e_{s} e_{a}\right)}{+\left(1+0,34 U_{2}\right)}$

From Eq. 1, ET $\mathrm{ET}_{0}$ is calculated for an area planted with a hypothetical reference crop that has an assumed height of $12 \mathrm{~cm}$, a fixed surface resistance of $70 \mathrm{~s} \mathrm{~m}^{-1}$, and an albedo of 0.23 . ET 0 depends on the net radiation $(\mathrm{Rn})$, the heat flux on the ground $(\mathrm{G})$, the air temperature measured $2 \mathrm{~m}$ from the ground $(\mathrm{T})$, the average wind speed $\left(\mathrm{U}_{2}\right)$, the saturation vapour pressure $\left(\mathrm{e}_{\mathrm{s}}\right)$, the actual vapour pressure $\left(e_{a}\right)$, the slope of the vapour pressure curve versus temperature $(\Delta)$, and the psychrometric constant $(\gamma)$.

\section{Determination of actual evapotranspiration $\left(\mathrm{ET}_{\mathrm{a}}\right)$ using the water balance}

$\mathrm{ET}_{\mathbf{a}}$ can be calculated using the water balance (Eq. 2) between two dates on which substrate moisture values were approximately the same; thus, the variation in moisture storage was zero $(\Delta \mathrm{V}=0)$. Under this premise $\mathrm{ET}_{\mathrm{a}}$ is the difference between the input water (rainfall and irrigation) and the output water (drainage). This condition was used for determining $\mathrm{ET}_{\mathrm{a}}$ in 2009, since no moisture sensors were installed that year. 
Input $($ rainfall + irrigation $)=$ Output $\left(\right.$ drainage $\left.+\mathrm{ET}_{\mathrm{a}}\right)+\Delta \mathrm{V}$

In 2010 and 2011 data from the moisture sensors were used to determine $\Delta \mathrm{V}$ and $\mathrm{ET}_{\mathrm{a}}$ could be calculated in a daily and monthly basis.

The condition of total water availability was maintained through most of 2010. Tracer tests that involved high water inputs were carried from December 2010 to May 2011. When tracer tests were performed, a restriction on irrigation was set in the second half of 2011 (June to December) in order to maintain the soil moisture at lower levels than those from June to December 2010.

\section{RESULTS AND DISCUSSION}

\section{Effect of amendments under total water availability}

Effect of the OM amendment

To test the effect of OM on the water balance, the values of $\mathrm{ET}_{\mathbf{a}}$ for P-2 (amended with $\mathrm{OM})$ and P-4 (100\% sand) are compared. Figure 3 shows that the $\mathrm{ET}_{\mathbf{a}}$ values for the two lysimeters are similar; in fact, for a few months (March, April, May and July. 2010), ETa in the P-2 is lower than the not amended lysimeter, while in other months (June, August, September and October 2010 ) it is up to $23 \%$ higher. The highest values of $\mathrm{ET}_{\mathrm{a}}$ were reached in June-August 2010: 2.76$12.2 \mathrm{~mm} /$ day in P-2 and 3.06-10.3 mm/day in P-4. These values are similar to those obtained by Green et al. (1990) and Bowman and Macaulay (1991): 7.7-12.7 mm/day and 4.57-13.0 mm/day, respectively. Research carried out in Norway by Aamlid et al. (2016) showed that, under daily irrigation conditions, they obtained $\mathrm{ET}_{\mathrm{a}}$ values of 5-10 mm/day, lower than P-2, probably due to climatic conditions. To achieve these results, they installed mini lysimeters on a green with Agrostis stolonifera -L-93.

Under this condition of total availability of water, the edaphic factor (in this case, the presence of $\mathrm{OM}$ ) is barely relevant and the presence of OM does not show its water retention capacity as Bigelow et al. (2004), Waltz et al. (2003) and McCoy et al. (2007) already showed in previous research. 


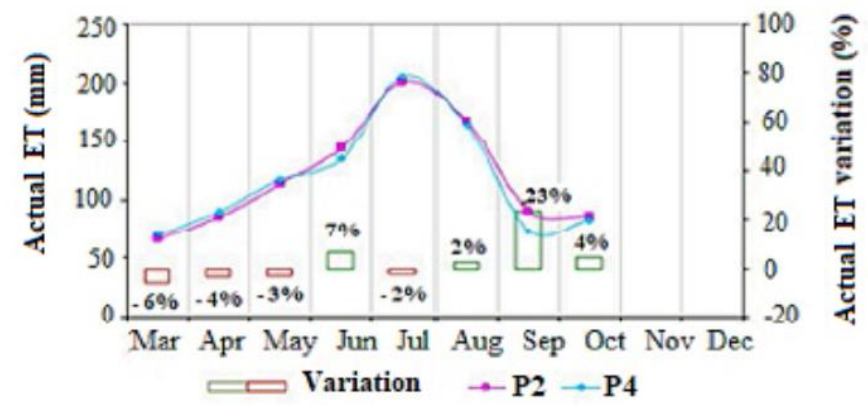

Figure 3. ET $\mathrm{a}_{\mathrm{a}}$ values for P-2 (OM) and P-4 (100\% sand), to show the effect of OM for 2010. $\mathrm{ET}_{\mathrm{a}}$ variation: difference between the $\mathrm{ET}_{\mathrm{a}}$ value of $\mathrm{P} 2$ and the $\mathrm{ET}_{\mathrm{a}}$ value of $\mathrm{P} 4$

Effect of the hydrogel amendment

Over the same period, $\mathrm{ET}_{\mathrm{a}}$ values of the lysimeters amended with hydrogel, P-1 and P-3, are greater than those for the not amended lysimeters, as shown in Figure 4A (P-1 compared with P-2, amended with OM) and 4B (P-3 compared with P-4, which is $100 \%$ sand). The moderate increase of $23 \%$ in the $\mathrm{ET}_{\mathrm{a}}$ of P-1 (OM and hydrogel), and the high increase of $61 \%$ for P-3 (hydrogel) may be explained by the ability of the hydrogel to retain water, which facilitated evaporation, and/or a high $K c$ value generated by transpiration. Mohawesh and Durner (2019) and Narjary et al. (2012) suggested that soil amendments, as hydrogel, improved soil water retentivity, across the whole moisture range saturation (from total water availability to water stress condition), and, also, improved the water availability of the sandy soils for a larger period (nearly 22 days). The $\mathrm{ET}_{\mathrm{a}}$ values achieved at P-1 and P-3 (P-1: 3.71-13.18 mm/day; P-3: 3.34-15.16 mm/day) exceed the maximum values of Green et al. (1990) (12.7 mm/day) and Bowman and Macaulay (1991) $(13.0 \mathrm{~mm} / \mathrm{day})$.
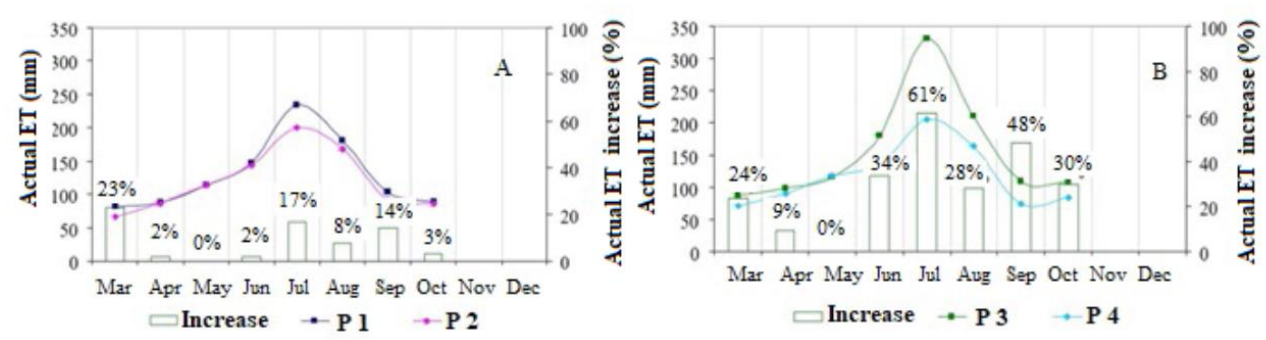

Figure 4. A) ET $\mathrm{a}_{\mathrm{a}}$ values for P-1 (hydrogel and OM) and P-2 (OM). $\mathrm{ET}_{\mathrm{a}}$ increase: percentage by which the $\mathrm{ET}_{\mathrm{a}}$ value of $\mathrm{P} 4$ increased with respect to $\mathrm{P} 2$. B) $\mathrm{ET}_{\mathrm{a}}$ values for P-3 (hydrogel) and P4 (100\% sand), to show the effect of the hydrogel for 2010. $\mathrm{ET}_{\mathrm{a}}$ increase: percentage by which 
the $\mathrm{ET}_{\mathrm{a}}$ value of $\mathrm{P} 3$ increased with respect to $\mathrm{P} 4$.

It is noteworthy that the increase in water storage under existing conditions of water availability may become more damaging to the grass than a lack of water, especially in summer. Surface water absorbs heat from the sun and transfers it to the root zone, such that the temperatures may be several degrees above the ambient temperature, causing damage to the roots (Dernoeden, 2006).

Monthly variations of $\mathrm{ET}_{\mathrm{a}}$ and $\mathrm{ET}_{0}$ between March 1st, 2010 and December 31st, 2011 for all lysimeters are presented in Figure 5. All the curves follow the same trend: the highest values are reached in the months from June to August and the lowest in the months from November to February.

It is important to point out that $\mathrm{ET}_{\mathrm{a}}$ values were greater than $\mathrm{ET}_{0}$ between July and August 2010 (total availability water) in all lysimeters and especially noticeable in the hydrogel treated P-1 and P-3. Detailed analysis indicated that, in these months, the water requirements (ETa) of P1 and P-3 are greater than $\mathrm{ET}_{0}$ (Figure 5), because of the extra water needed when air temperatures approach $30^{\circ} \mathrm{C}$. There is a clear influence of agronomic activities and the FAO-Penman-Monteith equation underestimates the water requirement. Qian et al. (1996) and Lecina y Martínez-Cob (2000) reached the same conclusion from studies of other grass varieties that had high values of evapotranspiration.

From March to June and September to November 2010 (Figure 5), when the temperature dropped, $\mathrm{ET}_{0}$ provided a reasonable reflection of the water requirement in the all lysimeters. Irrigation was increased when tracer tests were made in December 2010 and the moisture in the substrates was high. Excess moisture resulted in an increase in $\mathrm{ET}_{\mathrm{a}}$ in December in P-2 and P-3 (no data for P-4 and P-1), which shows that the level of moisture in the substrate also influenced the value of $\mathrm{ET}_{\mathrm{a}}$, as mentioned by Biran et al. (1981), and Kneebone and Pepper (1984).

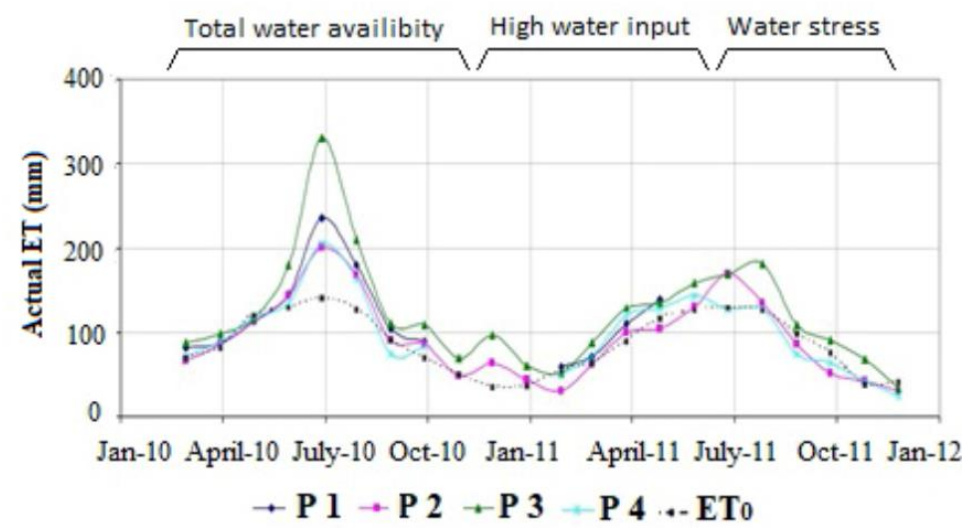


Figure 5. Monthly $\mathrm{ET}_{\mathrm{a}}$ and $\mathrm{ET}_{0}$ values for the period from March 1st, 2010 until December 31st, 2011 for P-1 (hydrogel and OM), P-2 (OM), P-3 (hydrogel) and P-4 (100\% sand)

\section{Effect of amendments under slight water stress condition}

A slight water stress was imposed in the period from June to December 2011 to determine if irrigation water could be saved in comparison to 2010. The result was a low-quality turf and a decline in the $\mathrm{ET}_{\mathrm{a}}$ in P-2 (with OM) and P-4 (sand) (there is no data for P-1); however, each lysimeter reacted differently to water deficit, depending on the amendment. Gómez-Armayones et al. (2017) showed that adverse effects of deficit irrigation on turfgrass quality are more evident when turf is subject to environmental and/or management stresses such as long intervals between irrigation, short mowing heights or high temperatures.

\section{Effect of the OM amendment}

Evapotranspiration in P-2 (OM) and P-4 (100\% sand) are compared in Figure 6. Given the water restriction from July to December 2011, the effect of the OM was manifested in a lower decrease in ET $\mathrm{a}_{\mathrm{a}}$ of P-2 that in the P-4. For example, in July 2011, a decrease of $13 \%$ in storage in $\mathrm{P} 2$ (Figure 6A) caused the $\mathrm{ET}_{\mathrm{a}}$ to decrease $16 \%$ (Figure 6B), while in $\mathrm{P}-4$, a 5\% decrease in storage in P-4 (Figure 6C) caused a decrease of 38\% in the ET $a$ (Figure 6D). In August 2011, the ratios were lower, but the $\mathrm{OM}$ still prevented a decrease in $\mathrm{ET}_{\mathrm{a}}$ and plant heat stress. In September, when the decrease in soil moisture was similar in both lysimeters, the $\mathrm{ET}_{\mathrm{a}}$ for $\mathrm{P}-2$ was still greater than that for P-4. The effect of OM was very low in October as the moisture was too low in P-2 (40\% less than in 2010); the $\mathrm{ET}_{\mathrm{a}}$ was therefore lower in P-2 than in P-4, for which the humidity was only $8 \%$, less than in the previous year. The values obtained by Aamlid et al. (2016) under non-irrigation conditions (one single irrigation at the beginning of the period) varied between 3 $5 \mathrm{~mm} /$ day, and in the P-2, for these stress conditions, $\mathrm{ET}_{\text {a }}$ presented values between 1.1 and 5.4 $\mathrm{mm} /$ day. In 2011, the difference in the behaviour of the substrates (edaphic factor) was not very evident as the standard condition of the FAO (total water availability) was kept in all lysimeters (2010). When the sand was amended with OM, the decline of $\mathrm{ET}_{\mathrm{a}}$ was minimized only under conditions of water deficit, and grass stress caused by high temperatures was reduced. 

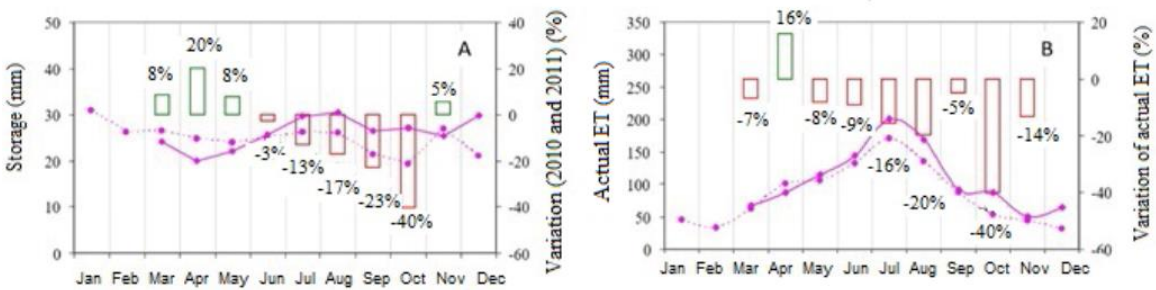

$\square$ Variation $\cdots 2011 \rightarrow 2010$

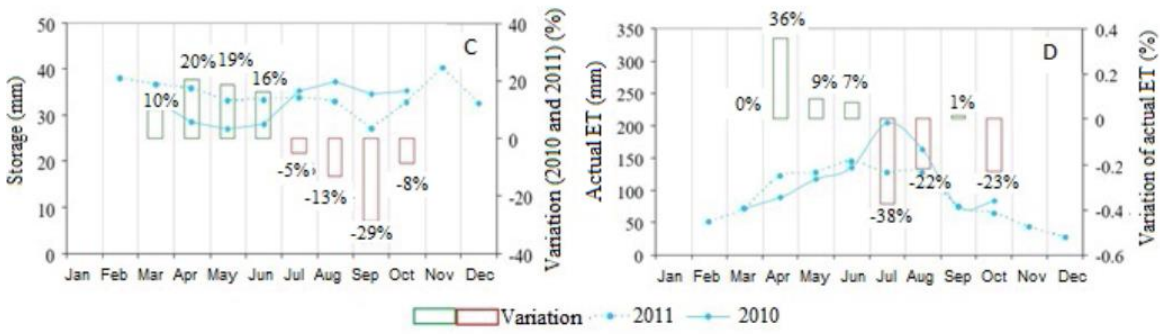

Figure 6. A) Values of the average monthly water storage for P-2 (OM), B) values of $\mathrm{ET}_{\mathrm{a}}$ for P$2(\mathrm{OM}), \mathrm{C})$ values of the average monthly water storage for P-4 (100\% sand), and D) values of $\mathrm{ET}_{\mathrm{a}}$ for P-4 (100\% sand), for 2010 and 2011. ET $\mathrm{a}$ variation: difference between the $2010 \mathrm{ET}_{\mathrm{a}}$ value and the $2011 \mathrm{ET}_{\mathrm{a}}$ value

When the water availability decreased, as occurred in the second half of 2011, the evapotranspiration rate was higher from the OM-amended lysimeter than from the $100 \%$ sandy lysimeter, which indicates that the retention capacity of OM was significantly lower than that of the hydrogel.

Effect of the hydrogel amendment

Hydrogel amended P-3 is compared with not amended P-4 (100\% sand) to determine the influence of hydrogel on $\mathrm{ET}_{\mathrm{a}}$ in Figure 7. It is shown that $\mathrm{P}-3$, despite of having a greater decrease in storage in the summer of 2011 (Figure 8) than P-4 (Figure 6C), has an $\mathrm{ET}_{\mathrm{a}}$ about $40 \%$ higher than P-4 from July to September, indicating that the hydrogel provided water to the roots that could be used by the plant (Narjary et al., 2012).

It appears that the distribution of water within the substrate, which in turn determines the availability to the grass, is more important than the amount of water stored; this is especially important in the summer months when the grass is facing heat stress. 


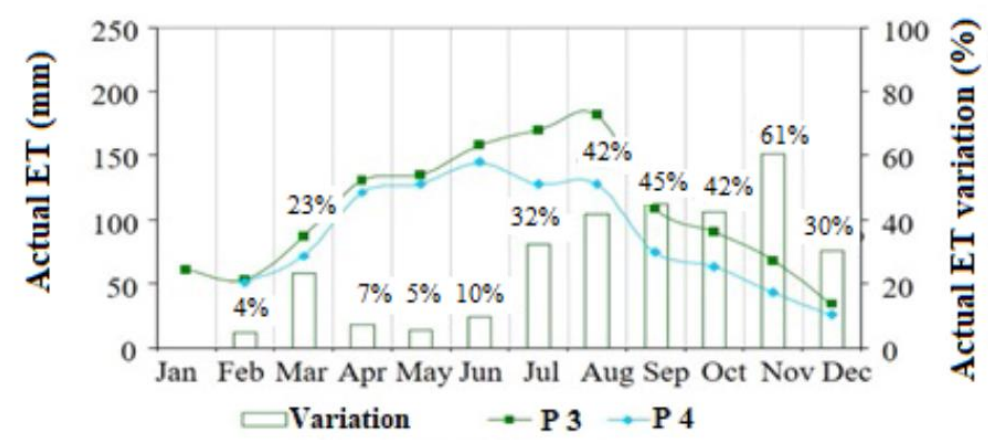

Figure 7. ET $\mathrm{a}_{\mathrm{a}}$ values for P-3 (hydrogel) and P-4 (100\% sand) in 2011 to highlight the effect of the hydrogel amendment. $\mathrm{ET}_{\mathrm{a}}$ variation: difference between the $\mathrm{ET}_{\mathrm{a}}$ value of $\mathrm{P} 3$ and the $\mathrm{ET}_{\mathrm{a}}$ value of P4

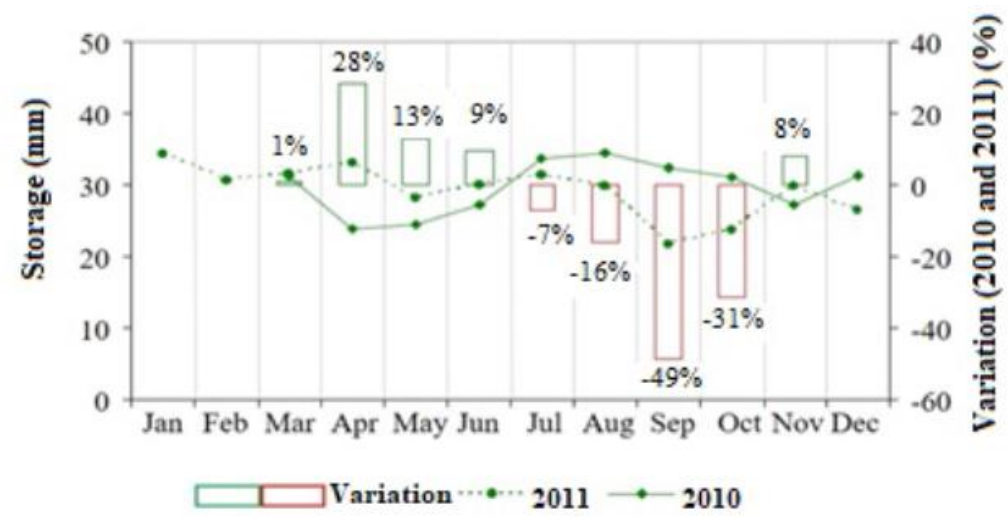

Figure 8. Comparison of the average monthly storage in P-3 (hydrogel) during 2010 and 2011.Storage variation: difference between the 2010 storage value and the 2011 storage value

Monthly variations of $\mathrm{ET}_{\mathrm{a}}$ and $\mathrm{ET}_{0}$ in the summer of 2011 (Figure 5), when the levels of humidity in the lysimeters were lower than in 2010, show values of $\mathrm{ET}_{\mathrm{a}}$ still deviated from $\mathrm{ET}_{0}$ in P-2 and P-3 but with a smaller gap; there was no difference however between the values for P4. Also, when the water availability decreased, as occurred in this second half of 2011, the $\mathrm{ET}_{\mathrm{a}}$ was lower for P-2 (with OM) than for P-3 (hydrogel), which indicates that the retention capacity of OM was significantly lower than that of the hydrogel. Values in P-1 could not be calculated because sensors were broken.

\section{$E T_{0}, \mathrm{ET}_{\mathrm{a}}$, and $K_{c}$ from the annual water balance}

To calculate $\mathrm{ET}_{\mathrm{a}}$ when $\Delta \mathrm{V}=0$ (variation in moisture storage was zero), we identified periods of time when the moisture profiles showed that the condition of total water availability 
was met (well watered condition). These events corresponded to a first interval from March 30th to September 22nd, 2009, a second interval between March 4th and October 12th, 2010, and a third interval from March, 12th to November, 21st, 2011. For these three intervals, daily values of $\mathrm{ET}_{0}$ were calculated from weather station data using the FAO-Penman-Monteith equation. $\mathrm{ET}_{\mathrm{a}}$ was calculated from water balance from the irrigation, drainage, and daily precipitation data. The $\mathrm{ET}_{\mathrm{a}}$ and crop coefficient, $\mathrm{K}_{\mathrm{c}}=\mathrm{ET}_{\mathrm{a}} / \mathrm{ET}_{0}$, are presented in Table I.

Table I shows that values of $\mathrm{K}_{\mathrm{c}}$ in year 2009 are smaller than those calculated for 2010 and 2011. It should be noted that the agronomic conditions in 2010 and 2011 were like the standard conditions of the FAO, but those in 2009 were very far from the standard, reducing the transpiration of the turf. This may be due to agronomic practices in 2009, the year in which the planting and establishment of the lawn took place (Martin del Campo et al., 2019).

Under the standard conditions maintained in 2010 and 2011, $\mathrm{ET}_{\mathrm{a}}$ is 10 to $50 \%$ bigger than $\mathrm{ET}_{0}$ depending on the amendment: the hydrogel amended P-1 and P-3 had the highest values of $\mathrm{K}_{\mathrm{c}}$ every year. The high values of $\mathrm{K}_{\mathrm{c}}$ of the P-1 and P-3 do not indicate higher water requirements; rather, evapotranspiration of the water retained by the hydrogel was increased since drainage was minimized, and storage showed less variation. Evaporation increases when the water is maintained in the first few centimetres of the profile; further, when there is water available for the roots, transpiration is facilitated, and is responsible for maintaining the temperature in the leaves and reducing heat stress (Throsell et al., 1987; Carrow, 1996; Liu and Huang, 2001; McCann and Huang, 2008).

The results show that, in 2010, the amount of water needed to maintain an acceptable quality of grass in P-2 (OM) and in P-4 (100\% sand) was between 16\% and 17\% higher than that determined by the weather station (ET), resulting in a $\mathrm{K}_{\mathrm{c}}$ value of 1.17-1.16; the values of $\mathrm{K}_{\mathrm{c}}$ for P-2 and P-4 in 2009 and 2011 - two years of low quality grass, were 0.99 and 0.92, and 1.04 and 1.11, respectively. Aamlid et al. (2016) determinate a $\mathrm{K}_{\mathrm{c}}$ of 2.39 on the first day after irrigation and 0.79 a subsequent day (mean following day) on an experimental green construed similar to P2. Labranche (2005) for mime grass and substrate obtained a $K_{c}$ of 0.85 . The range of values of $\mathrm{K}_{\mathrm{c}}$ between 0.8 and 1.09 obtained by Aronson et al. (1987) is low compared to those obtained in P-2 and P-4. The reason for this difference may be the lower water consumption of Poa, Festuca and Lolium varieties studied by Aronson et al. (1987) against the variety Agrostis stolonifera-L93, that presents greater capacity of transpiration as a resource to protect its photosynthetic metabolism from stress due to high temperatures (Liu and Huang, 2001). Maximum and minimum $\mathrm{K}_{\mathrm{c}}$ values for the hydrogel amended lysimeter (P1 and P4) were higher (P1: 1.09-1.26); P3: 1.041.52) than those from $\mathrm{P} 2$ and $\mathrm{P} 4$ because of the ability of this compound to retain water, which facilitated evapotranspiration. 
Table I. $\mathrm{ET}_{0}, \mathrm{ET}_{\mathrm{a}}$, and $\mathrm{K}_{\mathrm{c}}$ values for the water conditions $\Delta \mathrm{V}=0$ (P-1: hydrogel + OM, P-2:

OM, P-3: hydrogel, P-4:100\% sand; I: Irrigation, R: Rainfall, D: Drainage)

\begin{tabular}{ccccccc}
\hline \multicolumn{7}{c}{ March, 30-September, 22, 2009 } \\
\hline & $I(\mathrm{~mm})$ & $R(\mathrm{~mm})$ & $D(\mathrm{~mm})$ & $\mathrm{ET}_{\mathrm{a}}(\mathrm{mm})$ & $E T_{0}(\mathrm{~mm})$ & $K_{c}$ \\
\hline P-1 & 739 & 165 & 144 & 760 & 692 & 1.09 \\
$\mathrm{P}-2$ & 735 & 165 & 209 & 691 & 692 & 0.99 \\
$\mathrm{P}-3$ & 693 & 165 & 135 & 723 & 692 & 1.04 \\
$\mathrm{P}-4$ & 798 & 165 & 326 & 638 & 692 & 0.92 \\
\hline
\end{tabular}

\begin{tabular}{|c|c|c|c|c|c|c|}
\hline \multicolumn{7}{|c|}{ March, 4-October, 12, 2010} \\
\hline & $I(m m)$ & $R(\mathrm{~mm})$ & $D(m m)$ & $\mathrm{ET}_{\mathrm{a}}(m m)$ & $E T_{0}(\mathrm{~mm})$ & $K_{c}$ \\
\hline $\mathrm{P}-1$ & 919 & 279 & 211 & 987 & 783 & 1.26 \\
\hline P-2 & 1200 & 279 & 565 & 916 & 783 & 1.17 \\
\hline P-3 & 1260 & 279 & 347 & 1190 & 783 & 1.52 \\
\hline P-4 & 1070 & 279 & 446 & 906 & 783 & 1.16 \\
\hline \multicolumn{7}{|c|}{ March, 12 - November, 21, 2011} \\
\hline & $I(m m)$ & $R(\mathrm{~mm})$ & $D(\mathrm{~mm})$ & $\mathrm{ET}_{\mathrm{a}}(m m)$ & $E T_{0}(\mathrm{~mm})$ & $K_{c}$ \\
\hline $\mathrm{P}-1$ & 837 & 386 & 222 & 1000 & 833 & 1.20 \\
\hline P-2 & 1010 & 386 & 530 & 866 & 833 & 1.04 \\
\hline $\mathrm{P}-3$ & 1180 & 386 & 452 & 1120 & 833 & 1.33 \\
\hline P-4 & 1160 & 386 & 623 & 926 & 833 & 1.11 \\
\hline
\end{tabular}

$E T_{0}, \mathrm{ET}_{\mathrm{a}}$, and $K_{c}$ from the daily water balance

If moisture sensors are available, the variations in water storage between any two given times can be calculated, and the daily $\mathrm{ET}_{\mathrm{a}}$ can be obtained from the water balance equation. Monthly ET $\mathrm{E}_{\mathrm{a}}$ data is the result of the sum of the daily $\mathrm{ET}_{\mathrm{a}}$ values when enough storage data is available. For months with uncomplete data, monthly $\mathrm{ET}_{\mathrm{a}}$ was extrapolated.

Figure 9 shows that $\mathrm{ET}_{\mathrm{a}}$ and $\mathrm{ET}_{0}$ (daily data) follow the same trend but with a slight lag because of the interval chosen for the calculation. It also shows that, although the monthly $\mathrm{K}_{\mathrm{c}}$ value was greater than $1\left(K_{c}=1.08\right)$, the values of $\mathrm{ET}_{\mathrm{a}}$ did not always outperform $\mathrm{ET}_{0}$, but were sometimes above or below this value, indicating that the FAO-Penman-Monteith equation may overestimate or underestimate $\mathrm{ET}_{\mathrm{a}}$ in certain circumstances. 


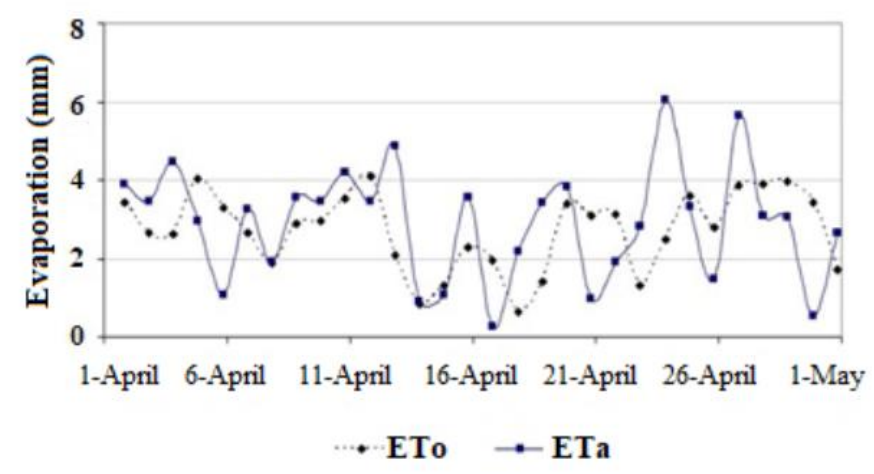

Figure 9. Daily $\mathrm{ET}_{\mathrm{a}}$ and $\mathrm{ET}_{0}$ values in P-1 (hydrogel and OM) for April, 2010

\section{CONCLUSIONS}

The results obtained in this research allow to verify the effect of the amendments with hydrogel and $\mathrm{OM}$ on the values of $\mathrm{ET}_{\mathrm{a}}$ and $\mathrm{K}_{\mathrm{c}}$.

The maximum and minimum $\mathrm{K}_{\mathrm{c}}$ values for lysimeters with hydrogel were higher than other lysimeters due to the ability of this compound to retain water. The water retention effect of the hydrogel generates a greater availability of water for the root system. Its effect is particularly noticeable in conditions of low humidity and high evapotranspiration (summer).

So, it is important to note that the addition of hydrogel can be a good measure to optimize the use of water without impairing the quality of the grass.

It is possible to observe, in all lysimeters, that when there is total availability of water (wellwatered conditions) $\mathrm{ET}_{\mathrm{a}}$ is greater or equal to $\mathrm{ET}_{0}$ and therefore $\mathrm{K}_{\mathrm{c}}$ is higher than 1.

The monthly variation of $\mathrm{K}_{\mathrm{c}}$ shows that the $\mathrm{ET}_{0}$, calculated from meteorological parameters seems to be a reliable measure of the annual water requirement. However, while adequate from rainy periods, it is inadequate from month with dry situations because of the high water requirement of the L-93 turf grass variety during summer, especially when the temperature exceeds $29^{\circ} \mathrm{C}$, above which the grass suffers heat stress. In such situations, the water requirement is $37 \%$ more than that calculated by replacing the $\mathrm{ET}_{0}$.

To maintain L-93 variety in optimal conditions, the $\mathrm{K}_{\mathrm{c}}$ must be higher or equal to 1.2, because the grass presents poor quality when the $\mathrm{K}_{\mathrm{c}}$ values are kept between 0.9 and 1.1.

\section{ACKNOWLEDGEMENT}


We acknowledge the Staff and Direction from Club de Campo del Mediterraneo Golf Course for their kind support.

\section{REFERENCES}

Aamlid TS, Larsbo M, Jarvis N. 2009. Effects of surfactant use and peat amendment on leaching of fungicides and nitrate from golf greens. Biologia 64(3):419-423. DOI:10.2478/s11756009-0094-7.

Aamlid TS, JKnox JW, Riley H, Kvalbein A, Pettersen T. 2016. Crop Coefficients, Growth Rates and Quality of Cool-Season Turfgrasses. Journal of Agronomy Crop Science 202:69-80. DOI: $10.1111 /$ jac.12130.

Akhter J, Mahmoo K, Malik KA, Mardan A, Ahmad M, Iqbal MM. 2004. Effects of hydrogel amendment on water storage of sandy loam and loam soils and seedling growth of barley, wheat and chickpea. Plant, Soil and Environment 50:463-469. DOI:10.17221/4059-PSE

Abedi-Koupai J, Sohrab F, Swarbrick, G. 2008. Evaluation of hydrogel application on soil water retention characteristics. Journal of Plant Nutrition 31(2):317-331. DOI:10.1080/01904160701853928.

Allen RG, Pereira LS, Raes D, Smith M. 1998. Crop evapotranspiration-guidelines for computing crop water requirements - FAO Irrigation and Drainage Paper, 56. Rome, Italy. ISBN $92-$ 5-104219-5.

American Society of Civil Engineers (ASCE). 1990. Evapotranspiration and irrigation water requirements: a manual prepared by the committee on irrigation water requirements, New York. ISBN: 0872627632

Amgain NR, Harris, DK, Thapa, SB. Marti, DL. Wu Y. Moss JQ. 2018. Evapotranspiration rates of turf bermudagrasses under nonlimiting soil moisture conditions in Oklahoma. Crop Science 58:1409-1415. DOI:10.2135/cropsci2017.08.0493.

Aronson LJ, Gold AJ, Hull RJ, Cisar JL. 1987. Evapotranspiration of cool-season turfgrasses in the humid northeast. Agronomy Journal 79:901-905. DOI:10.2134/agronj1987.00021962007900050029x.

Augustin B. 2000. Water requirements of Florida turfgrasses. University of Florida, IFAS, Coop. Exten. Pub. EP-024. UF/IFAS. Gainesville, Florida, USA.

Bigelow CA, Bowman DC, Cassel DK. 2000. Sand-based rootzone modification with inorganic soil amendments and sphagnum peat moss. USGA Green Section Record, 38:7-13.

Biran I, Bravdo B, Bushkin-Harav I, Rawitz, E. 1981. Water consumption and growth rate of 11 
turfgrasses as affected by mowing height, irrigation frequency, and soil moisture. Agronomy Journal 73:85-90. DOI:10.2134/agronj1981.00021962007300010020x

Blankenship TM. 2011. Water use characteristics of ten newly established cool-season turfgrass species. MSc Thesis. Oregon State University. Corvallis, Oregon, USA.

Bowman D, Macaulay L. 1991. Comparative evapotranspiration rates of tall fescue cultivars. HortScience, Vol 26(2): 122-123

Carrow RN. 1996. Summer decline of bentgrass greens. Golf Course Management, 64, 51-56.

Colmer TD, Barton L. 2017. A review of warm-Season turfgrass evapotranspiration, responses to deficit irrigation, and drought resistance. Crop Sci. 57: 98-110 DOI: 10.2135/cropsci2016.10.0911

DaCosta, M., Huang, B. 2006a. Minimum water requirements for creeping, colonial and velvet bentgrasses under fairway conditions. Crop Sci. 46:81-89. DOI:10.2135/cropsci2005.0118

DaCosta, M., Huang, B. 2006b. Deficit irrigation effects on water use characteristics of bentgrass species. Crop Sci. 46:1779-1786. DOI:10.2135/cropsci2006.01-0043

Dernoeden PH. 2006. Understanding wet wilt. Shedding some light on an unfamiliar subject. USGA Green Section Record, Mar-Apr 06.

Erwi, E, Koski A. 1998. Drought avoidance aspects and crop coefficients of Kentucky bluegrass and tall fescue turfs in the semiarid west. Crop Science 38:788-795. DOI:10.2135/cropsci1998.0011183X003800030028x.

Fu J, Fry J, Huang B. 2004. Minimum water requirements of four turfgrasses in the transition zone. Horticultural Science 39(7):1740-1744. DOI:10.21273/HORTSCI.39.7.1740.

Green R, Beard J, Casnoff D. (1990). Leaf blade stomatal characterizations and evapotranspiration rates of 12 cool-season perennial grasses. HortScience 25(7):760-761. DOI:10.21273/HORTSCI.25.7.760.

Gómez-Armayones C, Kvalbein A, Aamlid TS, Knox JW. 2018. Assessing evidence on the agronomic and environmental impacts of turfgrass irrigation management. Journal of Agronomy and Crop Science. 204(4): 333-346. DOI: 10.1111/jac.12265.

Huang B. 2006. Turfgrass water use and conservation strategies. Council for Agricultural Science and Technology (CAST). Water Quality and Quantity Issues for Turfgrasses in Urban Landscapes. city, country.

Kneebone WR, Pepper IL. 1984. Luxury water use by bermudagrass turf. Agronomy Journal 76:999-1002. DOI:10.2134/agronj1984.00021962007600060031x.

Labranche AJ. 2005. Creeping bentgrass, Kentucky Bluegrass and tall fescue responses to plant growth stimulants under deficit irrigation. MSc Thesis. Virginia Polytechnic Institute and State University. Blacksburg, Virginia, USA. 
Lecina S, Martínez-Cob A. 2000. Evaluación lisimétrica de la evapotranspiración de referencia semihoraria calculada con el método FAO Penman-Monteith. XVIII Congreso Nacional de Riegos, Huelva, España.

Liu X, Huang B. 2001. Seasonal changes and cultivar difference in turf quality, photosynthesis and respiration of creeping bentgrass. Horticultural Science 36(6): 1131-1135. DOI:10.21273/hortsci.36.6.1131.

Marin FR, Angelocci LR, Nassif, DSP. 2016. Crop coefficient changes with reference evapotranspiration for highly canopy-atmosphere couple crops. Agricultural Water Management. 163:139-145. DOI:10.1016/j.agwat.2015.09.010.

Martin del Campo MA, Esteller MV, Morell I, Expósito JL, Bandenay G, Diaz-Delgado C. 2019. A lysimeter study under field conditions of nitrogen and phosphorus leaching in a turf grass crop amended with peat and hydrogel. Science of the Total Environment 648: 530541. DOI:10.1016/j.scitotenv.2018.08.152.

McCann SE, Huang B. 2008. Evaluation of drought tolerance and avoidance traits for six creeping bentgrass cultivars. HortScience 43(2):519-528. DOI:10.21273/HORTSCI.43.2.519.

Mohawes O, Durner W. 2019. Effects of bentonite, hydrogel and biochar amendments on soil hydraulic properties from saturation to oven Dryness. Pedosphere 29(5):598-607. DOI:10.1016/S1002-0160(17)60426-0.

McCoy EL, Kunkel P, Prettyman GW, McCoy KR. 2007. Root zone composition effects on putting green soil water. Applied Turfgrass Science. 4(1)1-11. DOI:10.1094/ATS-20071119-02-RS.

Qian YL, Fry JD, Wiest SC, Upham WS. 1996. Estimating turfgrass evapotranspiration using atmometers and the Penman-Monteith model. Crop Science 36:699-704. DOI:10.2135/cropsci1996.0011183X003600030030x.

Rodriguez Diaz JA, Knox JW, Weatherhead EK. 2007. Competing demands for irrigation water: golf and agriculture in Spain. Irrigation and Drainage 56(5):541-549. DOI:10.1002/ird.317.

Shearman RC, Beard JB. 1973. Environmental and cultural preconditioning effects on the water use rate of Agrostis palustris Huds, cultivar Penncross. Crop Science 13:424-427. DOI:10.2135/cropsci1973.0011183X001300040010x.

Smith M, Allen RG, Monteith JL, Pereira LS, Pruitt WO. 1992. Report on the expert consultation on procedures for revision of FAO guidelines for prediction of crop water requirements. Land and Water Development Division. Food and Agriculture Organization of the United Nations. Rome, Italy.

Throssell CS, Carrow RN, Milliken GA. 1987. Canopy temperature based irrigation scheduling 
indices for kentucky bluegrass turf. Crop Science 27:126-131. DOI:10.2135/cropsci1987.0011183X002700010031x.

Ullah F, Othman MBH, Javed F, Ahmada Z, Akil HMd. 2015. Classification, processing and application of hydrogels: A review. Materials Science and Engineering C. 57, 414-433. DOI:10.1016/j.msec.2015.07.053.

Waltz F, Quisenberry V, McCarty L. 2003. Physical and hydraulic properties of rootzone mixes amended with inorganics for golf putting greens. Agronomy Journal 95:395-404. DOI:10.2134/agronj2003.3950.

Wherley B, Dukes MD, Cathey S. 2015. Consumptive water use and crop coefficients for warmseason turfgrass species in the Southeastern United States. Agricultural Water Management 156:10-18. DOI:10.1016/j.agwat.2015.03.020.

Xinmin Z, Lin H, Xiuju, Fah C, Xinzhang S. 2007. The most economical irrigation amount and evapotranspiration of the turfgrasses in Beijing, China. Agricultural Water Management 89:98-104. DOI:10.1016/j.agwat.2006.11.006.

Xu Q, Huang B. 2000. Effects of differential air and soil temperature on carbohydrate metabolism in creeping bentgrass. Crop Science, 40: 1368-1374. DOI: 10.2135/cropsci2000.4051368x.

Zhang X, Kang S, Zang L. 2010. Spatial variation of climatology monthly crop reference evapotranspiration and sensitivity coefficients in Shiyang river basin of northwest China. Agricultural Water Management 97:1506-1516. DOI:10.1016/j.agwat.2010.05.004. 
